EXETER

\title{
Firm Diversification and the Value of Corporate Cash Holdings
}

\author{
Zhenxu Tong \\ University of Exeter*
}

Paper Number: 08/03

First Draft: June 2007

This Draft: February 2008

\begin{abstract}
This paper studies how firm diversification affects the value of corporate cash holdings. We develop four hypotheses based on efficient internal capital market, agency problems, coinsurance effect, and shareholder-bondholder conflicts. We find that the value of cash holdings is lower in diversified firms than single-segment firms. We find that firm diversification is associated with a lower value of cash in both financially unconstrained and constrained firms, and that the value of cash is even lower for the diversified firms with more restrictions on shareholder rights. The findings are most consistent with the interpretation that firm diversification reduces the value of corporate cash holdings through agency problems.
\end{abstract}

JEL Classification: G32; G34

Keywords: Firm diversification; Corporate cash holdings

* Address: Xfi Centre for Finance \& Investment, School of Business and Economics, University of Exeter, Rennes Drive, Exeter EX4 4ST, United Kingdom. Telephone: +44 1392 263155. E-mail address: z.tong@exeter.ac.uk. I would like to thank Paolo Volpin, Gregory Connor, Chris Veld, and the seminar participants at University of Exeter for their comments and suggestions. 


\section{Introduction}

There is a large empirical literature that studies the impact of firm diversification on shareholder value. Lang and Stulz (1994), and Berger and Ofek (1995) find a significant diversification discount, and interpret the results as the evidences of value destruction by diversified firms. These findings have been challenged by a number of other papers. For example, Campa and Kedia (2002), and Graham, Lemmon and Wolf (2002) argue that the diversification discount is tainted by the endogeneity problems because firms with poor performance choose to diversify. A closely related literature studies through which channels firm diversification can exert its impact on firm value. The efficiency of the investments made by diversified firms has received substantial attentions from researchers. Shin and Stulz (1998), and Rajan, Servaes and Zingales (2000) find that the internal capital market in diversified firms engages in the cross-subsidization by allocation too much (little) to the divisions with low (high) investment opportunities. Whited (2001), however, raises methodological critiques on the measurement of divisional investment opportunities.

We contribute to the debate in this literature by studying an under-researched channel through which firm diversification can affect firm value: corporate cash holdings. First, corporate cash holdings occupy a significant role in the balance sheet. Bates, Kahle and Stulz (2006) find that the average cash to asset ratio for industrial firms increases from $10.48 \%$ to $24.03 \%$ between 1980 and 2004 . Opler, Pinkowitz, Stulz and Williamson (1999) show that mean of corporate cash holdings is greater 
than the mean of capital expenditures or the mean of acquisitions in their data. ${ }^{1}$ Given the magnitude of corporate cash holdings, this is a potentially important channel through which firm diversification can affect firm value. Second, while much work has been devoted to compare the efficiency of investments made by diversified firms and single-segment firms, we believe that it is necessary to study whether shareholders value financing resources (e.g., corporate cash holdings) differently between diversified firms and single-segment firms. This can provide a more general picture on the impact of firm diversification. Third, we can bypass the difficulty in measuring divisional investment opportunities in some extent by studying how shareholders value financing resources in diversified firms. Suppose corporate cash holdings are anticipated to be spent by the managers on the cross-subsidization (or the efficient internal capital allocation), shareholders will place a lower (or higher) value to the cash in diversified firms in the first place. In this case, although we do not directly observe divisional investment opportunities, we can still draw some implications based on how cash is valued.

We develop four hypotheses in this paper. First, firm diversification increases the value of cash holdings for financially constrained firms through efficient internal capital market, because more resources are allocated to the divisions with better investment opportunities (e.g., Stein, 1997). Second, firm diversification reduces the value of cash holdings through agency problems because firm diversification can be

\footnotetext{
1 See Opler, Pinkowitz, Stulz and Williamson (1999), p17. They show that the mean of the ratio Cash/Net Assets is 0.170. The mean of the ratio Capital Expenditures/Net Assets is 0.090, while the mean of the ratio Acquisitions/Net Assets is 0.011 .
} 
associated with empire building (e.g., Jensen, 1986) and cross-subsidization (e.g., Shin and Stulz, 1998; Rajan, Servaes and Zingales, 2000). Third, the value of cash holdings for financially constrained firms is lower if the firms are diversified, because the coinsurance effect from the imperfectly correlated cash flows among different divisions increases debt capacity (e.g., Lewellen, 1971). Fourth, firm diversification increases the value of cash holdings from a shareholder's perspective through the type of shareholder-bondholder conflicts proposed by Jensen and Meckling (1976). We empirically test these four hypotheses, and investigate which hypothesis is most relevant for the relation between firm diversification and the value of cash holdings.

We get a sample of 28563 firm-year observations from 1998 to 2005 . We use the methodology in Faulkender and Wang (2006) to study the value of corporate cash holdings. We find that the marginal value of one dollar in diversified (single-segment) firms is $\$ 0.92$ (\$1.08), implying that the same dollar is valued 16 cents less in diversified firms than single-segment firms. This is consistent with the interpretation that firm diversification on average reduces the value of cash holdings. We divide the sample into financially unconstrained and constrained firms, and find that the value of cash is lower for diversified firms in both sub-samples. We include a measure of corporate governance, and find that the value of cash holdings is even lower for the diversified firms with more restrictions on shareholder rights. We get consistent results when we use an alternative measure for the unexpected change in cash holdings and three econometric methods to control for the potential endogeneity problem. 
These findings are most consistent with the predictions of the agency hypothesis. We conclude that firm diversification reduces the value of corporate cash holdings through agency problems.

The remainder of the paper is organized as follows. Section 2 develops four hypotheses about the relation between firm diversification and the value of cash holdings. Section 3 discusses the data and describes the methodology. Section 4 examines how firm diversification affects the value of cash holdings. Section 5 concludes the paper.

\section{Hypothesis development}

We develop four hypotheses about the relation between firm diversification and the value of cash holdings in this section.

\subsection{Efficient internal capital market}

For a given amount of capital, the headquarters of a diversified firm have the control rights to allocate more resources to the divisions with better investment opportunities. Stein (1997) argues that this form of winner-picking increases the efficiency of internal capital allocation. We expect that among financially constrained firms, the value of corporate cash holdings is higher for diversified firms than single-segment firms. The winner-picking argument is relevant to financially constrained firms. If a firm is financially unconstrained, the firm can get the funding from external capital markets to finance good investment projects. We develop the 
following hypothesis.

Hypothesis 1: Firm diversification increases the value of cash holdings in financially constrained firms through efficient internal capital market.

\subsection{Agency problems}

Firm diversification can be associated with agency problems. At the firm-level, empire-building preferences will cause managers to excessively spend available funds on unprofitable investment projects (e.g., Jensen, 1986). Morck, Shleifer and Vishny (1990) find more negative market reactions when acquirors are engaging in unrelated diversification. At the segment-level, cross-subsidization can exist in diversified firms (e.g., Shin and Stulz, 1998). Cross-subsidization refers to the activities that corporate resources are diverted from the divisions with good investment opportunities to the divisions with poor investment opportunities. Agency problems reduce the value of cash holdings in a diversified firm because shareholders anticipate the inefficient use of cash. We develop the following hypothesis.

Hypothesis 2: Firm diversification reduces the value of cash holdings through agency problems.

\subsection{Coinsurance effect}

Cash flows generated by different divisions of a diversified firm are imperfectly correlated. Lewellen (1971) argues that this coinsurance effect can increase the debt capacity of a diversified firm. Faulkender and Wang (2006) find that the value of cash holdings is higher with the presence of greater financial constraints. Among financially constrained firms, we therefore expect that the value of corporate cash 
holdings is lower for diversified firms because the coinsurance effect reduces the magnitude of financial constraints. The argument of the coinsurance effect is relevant to financially constrained instead of unconstrained firms. We develop the following hypothesis.

Hypothesis 3: Firm diversification reduces the value of cash holdings in financially constrained firms through coinsurance effect.

\subsection{Shareholder-bondholder conflicts}

We focus on the value of cash holdings from a shareholder's perspective in this paper. Conflicts can arise between shareholders and bondholders when bankruptcy risk is present. Jensen and Meckling (1976) argue that shareholders can be viewed as holding a European call option on the value of the firm with the exercise price equal to the face value of the debt, exercisable at the maturity date of the debt issue. The value of cash holdings to shareholders is higher in the firms with lower bankruptcy risk, because the benefit of cash holdings will more likely accrue to shareholders instead of bondholders. Since firm diversification reduces the bankruptcy risk through imperfectly correlated cash flows generated by different divisions, we expect that the value of cash holdings is higher for the shareholders in diversified firms.

Hypothesis 4: Firm diversification increases the value of cash holdings from a shareholder's perspective through shareholder-bondholder conflicts in leveraged firms. 


\subsection{Combining the hypotheses}

We combine the above four hypotheses into the following table.

\begin{tabular}{|l|c|c|c|c|}
\hline & \multicolumn{3}{|c|}{ The impact of firm diversification on the value of cash holdings } \\
\hline & $\begin{array}{l}\text { Efficient internal } \\
\text { capital market }\end{array}$ & Agency problems & $\begin{array}{l}\text { Coinsurance } \\
\text { effect }\end{array}$ & $\begin{array}{l}\text { Shareholder- } \\
\text { bondholder conflicts }\end{array}$ \\
\hline $\begin{array}{l}\text { Financially } \\
\text { unconstrained firms }\end{array}$ & 0 & - & 0 & + \\
\hline $\begin{array}{l}\text { Financially } \\
\text { constrained firms }\end{array}$ & + & - & - & + \\
\hline
\end{tabular}

This table summarizes the predictions from the four hypotheses. A plus (minus) sign indicates a positive (negative) impact of firm diversification on the value of cash holdings. A zero sign indicates no relation between these two. The predictions are different for financially unconstrained firms and constrained firms in some hypotheses. We can find that these four hypotheses are empirically testable, because the predictions of the four hypotheses are different from each other.

\section{Data and Methodology}

We describe the data and the methodology in this section.

\subsection{Data}

We obtain segment-level data from Compustat/Segment database. We use Compustat/Industrial Annual database as the source for firm-level data. We obtain stock return data from CRSP. The sample period is from 1998 to 2005. The Statement of Financial Accounting Standards (SFAS) No. 131 was issued as a new standard for 
the reporting of segment information in 1997. Villalonga (2004a, 2004b), and Berger and Hann (2003) show that segment data before and after 1997 are not directly comparable to each other. Since we use the 2006 version of Compustat, we set the sample period from 1998 to 2005, using the data in the period after the implementation of SFAS 131 to ensure the comparability of data.

We match Compustat/Segment with Compustat/Industrial Annual and CRSP databases, and exclude the firms with incomplete data. Following the literature on firm diversification (e.g, Berger and Ofek, 1995), we exclude financial service firms and the firms with financial service segments (SIC codes between 6000 and 6999). We also require that the sum of segment sales is within $1 \%$ of the total sales of the firm. We define diversified firms as the firms that have at least two segments with different SIC codes. ${ }^{2}$ After these screening procedures, we obtain a final sample of 6867 firms with 28563 firm-year observations. The sample contains 10828 (17735) firm-year observations for diversified (single-segment) firms.

\subsection{Methodology}

Faulkender and Wang (2006) develop a methodology to measure the marginal value of cash holdings. We follow their method and develop the primary specification as follows.

\footnotetext{
${ }^{2}$ We obtain similar results by defining diversified firms as the firms that have at least two segments with different two-digit SIC codes.
} 


$$
\begin{aligned}
& \mathrm{R}_{\mathrm{i}, \mathrm{t}}-\mathrm{RB}_{\mathrm{i}, \mathrm{t}}=\mathrm{a}+\mathrm{b}_{1} * \frac{\Delta \text { Cash HoldingSi, }}{\mathrm{MV}_{\mathrm{i}, \mathrm{t}-1}}+\mathrm{b}_{2} * \text { Firm Diversification } \mathrm{i}, \mathrm{t} * \frac{\Delta \text { Cash Holdingsi, } \mathrm{t}}{\mathrm{MV}_{\mathrm{i}, \mathrm{t}-1}} \\
& +\mathrm{b}_{3} * \text { Firm Diversification }_{\mathrm{i}, \mathrm{t}}+\mathrm{b}_{4} * \frac{\Delta \text { Earningsi } \mathrm{t}}{\mathrm{MV}_{\mathrm{i}, \mathrm{t}-1}}+\mathrm{b}_{5} * \frac{\Delta \mathrm{Net}^{\mathrm{Assetsi}, \mathrm{t}}}{\mathrm{MVi,t-1}}+\mathrm{b}_{6} * \frac{\Delta \mathrm{R} \& \mathrm{Di}_{\mathrm{i}, \mathrm{t}}}{\mathrm{MV}_{\mathrm{i}, \mathrm{t}-1}}
\end{aligned}
$$

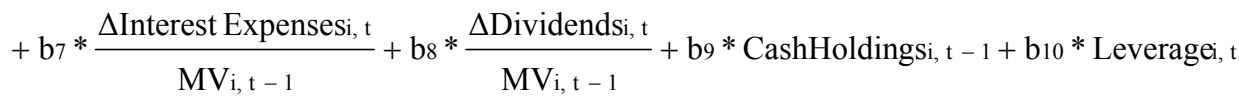

$$
\begin{aligned}
& +\mathrm{b}_{11} * \text { CashHoldingSi, } \mathrm{t}-1 * \frac{\Delta \text { Cash Holdingsi, } \mathrm{t}}{\mathrm{MV}_{\mathrm{i}, \mathrm{t}-1}}+\mathrm{b}_{12} * \text { Leverage } \mathrm{t} * \frac{\Delta \text { Cash HoldingSi, } \mathrm{t}}{\mathrm{MV}_{\mathrm{i}, \mathrm{t}-1}} \\
& +\mathrm{b}_{13} * \frac{\text { New Financing }_{\mathrm{i}, \mathrm{t}}}{\mathrm{MV} \mathrm{i}, \mathrm{t}-1}+\varepsilon \mathrm{i}, \mathrm{t}
\end{aligned}
$$

where $\Delta \mathrm{X}_{\mathrm{i}, \mathrm{t}}$ indicates a change in the variable $\mathrm{X}$ of firm $\mathrm{i}$ from year $\mathrm{t}-1$ to $\mathrm{t}$.

(e.g., $\Delta$ Cash Holdings $\mathrm{s}_{\mathrm{i}, \mathrm{t}}=$ Cash Holdings $_{\mathrm{i}, \mathrm{t}}-$ Cash Holdings $_{\mathrm{i}, \mathrm{t}-1}$ )

$\mathrm{R}_{\mathrm{i}, \mathrm{t}}=$ Stock return over fiscal year $\mathrm{t}-1$ to $\mathrm{t}$.

$\mathrm{RB}_{\mathrm{i}, \mathrm{t}}=$ Stock i's benchmark return over fiscal year t-1 to t. The benchmark portfolio is one of the 25 Fama and French portfolios formed on size and book-to-market.

$\mathrm{MV}_{\mathrm{i}, \mathrm{t}-\mathrm{1}}=$ Market value of equity at year $\mathrm{t}-1$ computed as price times shares outstanding

Firm Diversification $_{\mathrm{i}, \mathrm{t}}=\mathrm{A}$ dummy variable that equals 1 for diversified firms and 0 for single-segment firms.

Cash Holdings $\mathrm{s}_{\mathrm{i}, \mathrm{t}}=$ Cash and marketable securities at year $\mathrm{t}$.

Earnings $_{\mathrm{i}, \mathrm{t}}=$ Earnings before extraordinary items over fiscal year $\mathrm{t}-1$ to $\mathrm{t}$.

Net Assets $_{\mathrm{i}, \mathrm{t}}=$ Net assets (Total Assets - Cash Holdings) at year $\mathrm{t}$.

$R \& D_{i, t}=R \& D$ expenses over fiscal year $t-1$ to $t$.

Interest Expenses $_{i, t}=$ Interest expenses over fiscal year $\mathrm{t}-1$ to $\mathrm{t}$.

Dividends $_{\mathrm{i}, \mathrm{t}}=$ Common dividends over fiscal year $\mathrm{t}-1$ to $\mathrm{t}$.

Leverage $_{i, t}=$ Leverage (Debt $/$ Total Assets) at year $\mathrm{t}$.

New Financing ${ }_{i, t}=$ Net new equity issues (equity issued minus repurchases) + Net new debt issues (debt issued minus debt retired) over fiscal year $\mathrm{t}-1$ to $\mathrm{t}$.

This methodology essentially represents a long-run event study. The event is the unexpected change in cash holdings, while the event window is defined as the whole fiscal year. In the above equation, the dependent variable is excess stock return. It is calculated as the stock return of firm $i$ during a fiscal year $t\left(R_{i, t}\right)$ minus its benchmark return over the same period $\left(\mathrm{RB}_{\mathrm{i}, \mathrm{t}}\right)$. This left-hand-side variable is interpreted as the cumulative abnormal return during a fiscal year, which incorporates the market reaction to the unexpected change in corporate cash holdings. We use the 25 Fama 
and French portfolios formed on size and book-to-market as benchmark portfolios. For each firm-year observation, a firm is grouped into one of the 25 Fama and French portfolios based on the intersection between size and book-to-market. The return of the corresponding Fama and French portfolio is regarded as the benchmark return for the firm during that year.

We first define the unexpected change in cash holdings as the realized change in cash holdings. Then we use an alternative measure based on the net change in cash holdings. In the primary specification, we measure the change in cash holdings as the ratio of the change in cash and marketable securities (Compustat item \#1) over a fiscal year to the 1-year lagged market value of equity. Since both the dependent variable and the independent variable are scaled by the 1-year lagged market value of equity, the coefficient represents the dollar change in shareholder value resulting from one-dollar change in the amount of cash held by the firm. We can interpret this as the marginal value of one dollar to the shareholders of the firm.

We construct an interaction term, Firm Diversification $* \Delta$ Cash Holdings. Firm Diversification is a dummy variable that equals 1 for diversified firms and 0 for single-segment firms. The coefficient of this interaction term represents the difference in the marginal value of one dollar between diversified firms and single-segment firms, thus indicating the impact of firm diversification on the value of cash holdings. We also include the Firm Diversification dummy in the regression to ensure that the estimated coefficient of the interaction term is due to the interaction, and not due to firm diversification itself. 
We include other control variables in the regression as suggested by Faulkender and Wang (2006). They argue that the value of cash holdings depends on both leverage and the lag of cash holdings, and include the interaction terms between these two variables and the change in cash holdings in the regression. We control for sources of value other than cash (earnings, net assets, $R \& D$, interest expenses, dividends, and new financing). We provide more details on the definition of the variables in the Appendix. Table 1 provides summary statistics for the sample. We winsorize the data to reduce the impact of outliers.

\section{Results}

We report the results in this section. We first present the relation between firm diversification and the value of cash holdings in the entire sample. Then we demonstrate the results by dividing the sample into financially unconstrained firms and constrained firms. Next, we add a measure of corporate governance and investigate its impact. Finally, we report the results using an alternative measure for unexpected changes in cash holding as well as three econometric methods to control for the potential endogeneity problem.

\subsection{The value of cash holdings}

Our primary objective is to measure the average impact of firm diversification on the value of cash holdings. The results are presented in Table 2. We first examine the marginal value of cash holdings in the entire sample, and report the results in the first 
and the second column. In this regression, an extra dollar in cash will affect a firm's excess return through the item $\Delta$ Cash Holdings and the interaction terms (Cash Holding $_{\mathrm{t}-1} * \Delta$ Cash Holdings and Leverage $* \Delta$ Cash Holdings). We need to use the coefficients of these items to obtain the marginal value. The calculation is as follows: The mean firm has the lag of cash holdings equivalent to $16.56 \%$ of the market capitalization of equity, and the mean leverage ratio is $20.14 \%$. Therefore, the marginal value of one dollar to shareholders in the mean firm is $\$ 1.02(=1.245+$ $(-0.726 * 16.56 \%)+(-0.509 * 20.14 \%))$

In the third and fourth column of Table 2, we report the average impact of firm diversification on the value of corporate cash holdings. This regression follows the primary specification as indicated in equation (1). To calculate the marginal value of cash holdings for single-segment firms, we need to use the coefficients of the same three items as before ( $\Delta$ Cash Holdings, Cash Holding $\mathrm{t}_{\mathrm{t}-1} * \Delta$ Cash Holdings, and Leverage $* \Delta$ Cash Holdings). We find that the marginal value of one dollar to shareholders in single-segment firms is $\$ 1.08$. To calculate the marginal value of cash holdings for diversified firms, we need to use the coefficient of the interaction term Firm Diversification * $\Delta$ Cash Holdings. Therefore, the marginal value of one dollar to shareholders in diversified firms is $\$ 0.92(=1.295+(-0.160)+(-0.741 * 16.56 \%)+$ $(-0.478 * 20.14 \%))$

These results indicate that an extra dollar in diversified firms on average is valued 16 cents ( $p$-value $=0.01)$ less than an extra dollar in single-segment firms. It implies that firm diversification reduces the value of cash holdings. The results are consistent 
with two hypotheses: agency problems and coinsurance effect. Although the coinsurance effect hypothesis only predicts a negative relation between firm diversification and the value of cash holdings for financially constrained firms, we may still find a negative coefficient in the entire sample. We therefore proceed to conduct the tests by dividing the sample into financially unconstrained and constrained firms.

\subsection{Financial constraints}

The four hypotheses make different predictions on the relation between firm diversification and the value of cash holdings depending on whether or not a firm is financially constrained. We design three criteria of financial constraints based on the measures used in the previous literature. We use the lagged variables as the measure of the criteria. Since lagged variables are pre-determined, they are less likely subject to the endogeneity problem.

\subsubsection{The criteria of financial constraints}

Firm size. Larger firms are better known and have better access to capital markets than smaller firms. Therefore larger firms face fewer constraints when raising external capital to finance their investments. We use the logarithm of total assets as the measure for firm size. For every year of the sample period, we rank all firms by their size at year $\mathrm{t}-1$, and assign a firm to the financially unconstrained (constrained) group if its lagged size is above (below) the mean of the annual size distribution.

Firm size and payout. Fazzari, Hubbard and Peterson (1988) state that financially constrained firms have lower payout ratios. Firms with higher payout ratios are more 
likely to have sufficient internal resources to finance their investments. We combine payout ratios with firm size to get the second criteria. We use the ratio of dividends to total assets as the measure for the payout ratio. For every year of the sample period, we sort all firms according to their payout ratios at year $\mathrm{t}-1$, and assign a firm to the financially unconstrained (constrained) group if the firm concurrently meets two criteria: its lagged size is above (below) the mean of the annual size distribution; its lagged payout ratio is above (below) the mean of the annual payout distribution.

Firm size and credit rating. Firms with a credit rating have better access to public debt markets. They are usually better known, and have less difficulty in raising external funds to finance their investments. We combine credit rating with firm size to get the third criteria. For every firm-year observation, we get the data for long-term issuer credit rating at year t-1 from Compustat, and assign a firm to the financially unconstrained (constrained) group if the firm concurrently meets two criteria: its lagged size is above (below) the mean of the annual size distribution; its lagged long-term issuer credit rating is available (unavailable). ${ }^{3}$

\subsubsection{Results}

Table 3 presents the results by dividing the sample into financially unconstrained and constrained firms according to the three criteria, and reports the marginal value of cash below the regressions. Panel A, B and C report the results using each of the three criteria. We find that the coefficients of the interaction term, Firm Diversification * $\Delta$ Cash Holdings, are both negative and significant in all the three panels, supporting

\footnotetext{
${ }^{3}$ We combine firm size with payout/credit rating because a firm is more unconstrained or constrained under these criteria. We get consistent results if we separately use payout/credit rating as the criteria.
} 
the interpretation that firm diversification reduces the value of cash holdings in both financially unconstrained firms and constrained firms. Among the predictions of the four hypotheses, the findings are most consistent with the agency hypothesis that predicts a lower value of cash holdings in diversified firms, no matter the firms are financially unconstrained or constrained.

\subsection{Corporate governance}

We conduct an additional test that more explicitly examines the impact of agency problems on the value of cash holdings. The negative impact from agency problems is more severe in a diversified firm with poor corporate governance. Therefore we expect that the value of cash holdings is even lower for a diversified firm with poor corporate governance. We use the data on corporate governance to examine this additional prediction of the agency hypothesis. Gompers, Ishii and Metrick (2003) construct a corporate governance index with the data on corporate charters of takeover defenses from the Investor Responsibility Research Center (IRRC) database. A higher Gompers et al. index indicates more restrictions on shareholder rights, thus corresponding with poorer corporate governance. ${ }^{4}$ The IRRC database only provides the data for a subset of firms (mostly larger firms) in the sample. We conduct the analysis with this subsample that contains 8242 firm-year observations.

We construct a triple interaction term, Firm Diversification $* \Delta$ Cash Holdings

* Poor Governance. Poor Governance is a dummy variable that equals 1 if the Gompers et al. index of a firm is within the top 90 percentile of the subsample

\footnotetext{
${ }^{4}$ Gompers et al. index has a possible range from 1 to 24. See Gompers, Ishii and Metrick (2003) for more details.
} 
(Gindex $\geq 12$ ) and 0 otherwise. This interaction term represents the difference in the value of cash holdings between a diversified firm with fewer restrictions on shareholder rights and a diversified firm with more restrictions on shareholder rights. We use a different cutoff point where the Gompers et al. index of a firm is within the top 75 percentile of the subsample (Gindex $\geq 11$ ) as the robustness check. We also include the Poor Governance dummy in the regression to ensure that the estimated coefficient of the triple interaction term is due to the interaction, and not due to poor corporate governance itself.

Table 4 presents the findings. We find that the coefficient of the triple interaction term, Firm Diversification * $\Delta$ Cash Holdings * Poor Governance, is negative and significant. We calculate the marginal value of cash holdings and report the results below the regressions. While an extra dollar is worth $\$ 0.83$ in a diversified firm with fewer restrictions on shareholder rights, the same dollar is only worth between $\$ 0.53$ and $\$ 0.58$ in a diversified firm with more restrictions on shareholder rights. These results support the interpretation that the value of cash holdings is even lower in a diversified firm with more restrictions on shareholder rights.

\subsection{Alternative measure of the unexpected change in cash holdings}

Our primary specification essentially represents a long-term event study. The excess return reflects the market reaction to the unexpected changes in cash holdings. We follow Faulkender and Wang (2006) and repeat our analysis using the net change in cash holdings defined as the realized change in cash holdings minus the average change in cash holdings in the corresponding benchmark portfolio over the same 
period. There is an additional advantage to use the net change in cash holdings. Bates, Kahle and Stulz (2006) document a time trend in the level of cash holdings. We expect that the time trend is present in both a firm's realized change in cash holdings and the average change in cash holdings in the corresponding benchmark portfolio. We therefore can reduce the impact of the time trend by using the net change in cash holdings.

Table 5A shows that an extra dollar is worth $\$ 1.08$ (\$0.93) for single-segment (diversified) firms. We repeat the analysis on the marginal value of cash for financially unconstrained firms and constrained firms, and report the results using firm size as the criteria of financial constraints in this table. We get consistent results using the other two financial constraints criteria. The results are similar to those presented above. Firm diversification reduces the value of cash holdings in both financially unconstrained firms and constrained firms. Table 5B presents the results using the net change in cash holdings with corporate governance variables. While an extra dollar is worth between $\$ 0.83$ and $\$ 0.86$ in a diversified firm with fewer restrictions on shareholder rights, it is only worth between $\$ 0.52$ and $\$ 0.54$ in a diversified firm with more restrictions on shareholder rights.

\subsection{About the endogeneity}

Campa and Kedia (2002) argue that firm diversification can be an endogenous choice made by a firm, and use econometric techniques to control for the potential endogeneity problem. Other papers in the literature have expressed the similar concern (e.g., Graham, Lemmon and Wolf, 2002). We follow Campa and Kedia (2002) 
and use three econometric methods to examine the impact of firm diversification on the value of cash holdings controlling for the endogeneity problem.

\subsubsection{Methodology}

The three econometric methods are the Heckman two-stage estimation, instrumental variables estimation and fixed effect estimation. Each of them addresses the endogeneity problem from a different perspective.

We apply the Heckman two-stage estimation to control for a firm's self selection into diversification. In the first stage, we estimate a probit regression to model the decision of a firm to diversify. The variables are motivated by Campa and Kedia (2002). They include various firm-specific, industry and macroeconomic characteristics that can influence a firm's decision to diversify. Since some two-year lagged variables (size, EBIT, and capital expenditures) are used in the probit regression, it slightly reduces the sample size to 27767 firm-year observations due to incomplete data. Table $6 \mathrm{~A}$ demonstrates the probit regression. We obtain the Lambda from the probit estimates. The calculation of Lambda follows the standard of the Heckman two-stage methodology, and is reported in the Appendix. In the second stage, we estimate the regressions with the Lambda as an additional control variable. This provides the treatment for a firm's self-selection into diversification.

We use instrumental variables estimation to examine the underlying causal relations. We follow Campa and Kedia (2002) and use the estimated probability of diversification from the probit model as a generated instrument. In the first stage, we use all the exogenous variables and the probability of diversification as explanatory 
variables in the decision to diversify. In the second stage, we use the fitted value from the first stage as an instrument for diversification to evaluate the effect of diversification on the value of cash holdings. Campa and Kedia (2002) provide more details on the rationales of this methodology.

We introduce a two-way fixed effect estimation to account for the omitted variable problem. Fixed firm effects and year effects are used to control for unobservable firm characteristics and time effects. We exclude the firms with only one observation during the sample period in order to estimate the fixed effect regression, thus leaving 27151 firm-year observations in the sample.

\subsubsection{Results}

We report the results using the three econometric methods on the entire sample in Table 6B. The first and second columns show the second stage of the Heckman two-stage estimation. We find that the marginal value of one dollar is $\$ 0.93$ (\$1.08) for diversified (single-segment) firms. The third and the fourth columns report the second stage of the instrumental variables estimation. The marginal value of one dollar is $\$ 0.76$ (\$1.09) for diversified (single-segment) firms. We find that the coefficient of the interaction term, Firm Diversification * $\Delta$ Cash Holdings, is -0.334 , implying that the instrumental variables estimation reveals a more negative impact of diversification on the value of cash. The fifth and the sixth columns show the results using fixed effect estimation. We find that an additional dollar is worth $\$ 0.95$ (\$1.07) in diversified (single-segment) firms. These results are consistent with the interpretation that firm diversification reduces the value of cash controlling for the 
potential endogeneity problem.

We report the results using size as financial constraints criteria and corporate governance variables in Table 6C. This table only shows the results of the Heckman two-stage estimation for brevity. We get consistent results using the other two econometric methods as well as the other two criteria of financial constraints. We find that firm diversification reduces the value of cash holdings in both financially unconstrained and constrained firms. An extra dollar in diversified firms is worth between $\$ 0.92$ and $\$ 0.96$, while it is worth between $\$ 1.05$ and $\$ 1.11$ in single-segment firms. Corporate governance has an additional impact on the value of cash holdings in diversified firms. We find that an extra dollar only worth $\$ 0.50$ in a diversified firm with more restrictions on shareholder rights. These results give further support to the agency hypothesis controlling for the potential endogeneity problem.

\subsection{Subsample with positive leverage}

The hypothesis based on shareholder-bondholder conflicts is related with leveraged firms. We conduct robustness checks for the subsample with positive leverage. We repeat the above analysis and find similar results in all the main specifications. 


\section{Conclusion}

We study the relation between firm diversification and the value of corporate cash holdings. We develop four hypotheses based on different theories of firm diversification. We use the methodology in Faulkender and Wang (2006), and find that the marginal value of one dollar in diversified (single-segment) firms is $\$ 0.92$ (\$1.08). The findings imply that the same dollar is valued 16 cents less in diversified firms than single-segment firms. We find that firm diversification reduces the value of cash in both financially unconstrained and constrained firms, and that the value of cash is even lower for the diversified firms with more restrictions on shareholder rights. We obtain similar results when we use an alternative measure for the unexpected change in cash holdings and three econometric methods to control for the potential endogeneity problem.

These findings are most consistent with the predictions of the agency hypothesis. We conclude that firm diversification reduces the value of corporate cash holdings through agency problems. 


\section{Appendix: Definition of the Variables}

\begin{tabular}{|c|c|}
\hline $\mathrm{R}_{\mathrm{i}, \mathrm{t}}$ & $R_{i, t}$ is stock return over fiscal year $\mathrm{t}-1$ to $\mathrm{t}$. \\
\hline $\mathrm{RB}_{\mathrm{i}, \mathrm{t}}$ & $\begin{array}{l}R B_{i, t} \text { is stock i's benchmark return over fiscal year } \mathrm{t}-1 \text { to } \mathrm{t} \text {. The benchmark portfolio } \\
\text { is one of the } 25 \text { Fama and French portfolios formed on size and book-to-market. }\end{array}$ \\
\hline Excess Return & Excess Return is defined as $\mathrm{R}_{\mathrm{i}, \mathrm{t}}-\mathrm{RB}_{\mathrm{i}, \mathrm{t}}$. \\
\hline $\mathrm{MV}_{\mathrm{i}, \mathrm{t}-1}$ & $\begin{array}{l}M V_{i, t-l} \text { is market value of equity at time t-1 computed as price (Compustat item } \\
\# 199) \text { times shares outstanding }(\# 25) \text {. }\end{array}$ \\
\hline Cash Holdings & Cash Holdings is defined as cash and marketable securities (\#1). \\
\hline Earnings & $\begin{array}{l}\text { Earnings is defined as earnings before extraordinary items }(\# 18+\# 15+\# 50+ \\
\# 51) \text {. }\end{array}$ \\
\hline Net Assets & Net Assets is defined as total assets minus cash holdings $(\# 6-\# 1)$. \\
\hline $\mathrm{R} \& \mathrm{D}$ & $R \& D$ is defined as research and development expenses (\#46). \\
\hline Interest Expenses & Interest Expenses is defined as interest expenses (\#15). \\
\hline Dividends & Dividends is defined as common dividends (\#21). \\
\hline New Financing & $\begin{array}{l}\text { New Financing is defined as net new equity issues (\#108-\#115) plus net new debt } \\
\text { issues (\#111-\#114). }\end{array}$ \\
\hline Leverage & $\begin{array}{l}\text { Leverage is defined as the sum of long-term debt (\#9) and debt in current liability } \\
(\# 34) \text { divided by total assets (\#6). }\end{array}$ \\
\hline Firm Diversification & $\begin{array}{l}\text { Firm Diversification is a dummy variable that equals } 1 \text { for diversified firms and } 0 \\
\text { for single-segment firms. }\end{array}$ \\
\hline Poor Governance & $\begin{array}{l}\text { Poor Governance is a dummy variable that equals } 1 \text { if the Gompers et al. index of a } \\
\text { firm is within the top } 90 \text { percentile (or top } 75 \text { percentile as an alternative cutoff } \\
\text { point) of the subsample. }\end{array}$ \\
\hline \multirow[t]{3}{*}{ Lambda } & $\begin{array}{l}\text { We assume that a firm's decision to diversify is determined by: } \\
\qquad \begin{array}{l}D_{\text {it }} *=\gamma Z_{i t}+u_{i t} \\
\qquad D_{i t}=1 \text {, if } D_{i t}{ }^{*}>0 \\
\qquad D_{i t}=0 \text {, if } D_{i t}{ }^{*}<0\end{array} \\
\text { where: } D_{i t} * \text { is an unobservable latent variable. } D_{i t} \text { is a dummy variable ( } 1 \text { for } \\
\text { diversified firms, and } 0 \text { for single-segment firms). } Z_{i t} \text { is a set of variables that } \\
\text { affect a firm's decision to diversify. } u_{i t} \text { is an error term. } \\
\text { We first estimate the above equation using a probit model to get the estimates of } \gamma \\
\text { denoted by } \gamma_{\mathrm{e}} \text {. }\end{array}$ \\
\hline & $\begin{array}{l}\text { Lambda is calculated as follows: } \\
\qquad \operatorname{Lambda}_{\mathrm{it}}=\frac{\phi\left(\gamma_{\mathrm{e}} \mathrm{Z}_{\mathrm{it}}\right)}{\Phi\left(\gamma_{\mathrm{e}} \mathrm{Z}_{\mathrm{it}}\right)} * \mathrm{D}_{\mathrm{it}}+\frac{-\phi\left(\gamma_{e} Z_{\mathrm{it}}\right)}{1-\Phi\left(\gamma_{\mathrm{e}} \mathrm{Z}_{\mathrm{it}}\right)} *\left(1-\mathrm{D}_{\mathrm{it}}\right)\end{array}$ \\
\hline & $\begin{array}{l}\text { where: } \phi \text { is the density function of the standard normal distribution. } \Phi \text { is the } \\
\text { cumulative distribution function of the standard normal distribution. } D_{\text {it }} \text { is a } \\
\text { dummy variable ( } 1 \text { for diversified firms, and } 0 \text { for single-segment firms). }\end{array}$ \\
\hline
\end{tabular}




\section{References}

Almeida, H., Campello, M., Weisbach, M., 2004, The cash flow sensitivity of cash, Journal of Finance 59, 1777-1804.

Bates, T., Kahle, K., Stulz, R., 2006, Why do U.S. firms hold so much more cash than they used to? Unpublished working paper, University of Arizona.

Berger, P., Ofek, E., 1995, Diversification's effect on firm value, Journal of Financial Economics 37, 39-65.

Berger, P., Hann, R, The impact of SFAS No. 131 on information and monitoring, Journal of Accounting Research 41, 163-223.

Campa, J., Kedia, S., 2002, Explaining the diversification discount, Journal of Finance 57, 1731-1762.

Dimitrov, V., Tice, S., 2006, Corporate diversification and credit constraints: Real effects across the business cycle, Review of Financial Studies 19, 1465-1498.

Dittmar, A., Mahrt-Smith, J., 2007, Corporate governance and the value of cash holdings, Journal of Financial Economics 83, 599-634.

Dittmar, A., Mahrt-Smith, J., Servaes, H., 2003, International corporate governance and corporate cash holdings, Journal of Financial and Quantitative Analysis 38, 111-133.

Faulkender, M., Wang, R., 2006, Corporate financial policy and the value of cash, Journal of Finance 61, 1957-1990.

Fazzari, S., Hubbard, R., Petersen, B., 1988, Financing constraints and corporate investment, Brookings Papers on Economic Activity, 141-195.

Foley, C., Hartzell, J., Titman, S., Twite, G., 2006, Why do firms hold so much cash? A tax-based explanation, Journal of Financial Economics, forthcoming.

Gompers, P., Ishii, J., Metrick, A., 2003, Corporate governance and equity prices, Quarterly Journal of Economics 118, 107-155.

Graham, J., Lemmon, M., Wolf, J., 2002, Does corporate diversification destroy value, Journal of Finance 57,695-720.

Harford, J., 1999, Corporate cash reserves and acquisitions, Journal of Finance 54, 1969-1997. 
Harford, J., Mansi, S., Maxwell, F., 2007, Corporate governance and firm cash holdings, Journal of Financial Economics, forthcoming.

Hubbard, R., Palia, D., 1999, A re-examination of the conglomerate merger wave in the 1960s: an internal capital markets view, Journal of Finance 54, 1131-1152.

Jensen, M., 1986, Agency costs of free cash flow, corporate finance, and takeovers, American Economic Review 76, 323-329.

Jensen, M., Meckling, W., 1976, Theory of the firm: Managerial behavior, agency costs and ownership structure, Journal of Financial Economics 3, 305-360.

Kim, C., Mauer, D., Sherman, A., 1998, The determinants of corporate liquidity: theory and evidence, Journal of Financial and Quantitative Analysis 33, 335-59.

Lamont, O., 1997, Cash flow and investment: evidence from internal capital markets, Journal of Finance 52, 83-109.

Lang, L., Stulz, R., 1994, Tobin's $q$, corporate diversification, and firm performance, Journal of Political Economy 102, 1248-1280.

Lewellen, W., 1971, A pure financial rationale for the conglomerate merger, Journal of Finance 26, 521-537.

Mansi, S., Reeb, D., 2002, Corporate diversification: what gets discounted? Journal of Finance 57, $2167-2183$.

McDonald, I., 2006, Capital pains: big cash hoards, Wall Street Journal, July 21, 2006.

Mikkelson, W., Partch, M., 2003, Do persistent large cash reserves hinder performance? Journal of Financial and Quantitative Analysis 38, 275-294.

Morck, R., Shleifer, A., Vishny, R., 1990, Do managerial objectives drive bad acquisitions? Journal of Finance 45, 31-48.

Opler, T., Pinkowitz, L., Stulz, R., Williamson, R., 1999, The determinants and implications of corporate cash holdings, Journal of Financial Economics 52, 3-46.

Pinkowitz, L., Stulz, R., Williamson, R., 2006, Does the contribution of corporate cash holdings and dividends to firm value depend on governance? A cross-country analysis, Journal of Finance, forthcoming.

Pinkowitz, L., Williamson, R., 2001, Bank power and cash holdings: Evidence from Japan, Review of Financial Studies 14, 1059-1082. 
Rajan, R., Servaes, H., Zingales, L., 2000, The cost of diversity: the diversification discount and inefficient investment, Journal of Finance 55, 35-80.

Shin, H., Stulz, R., 1998, Are internal capital markets efficient? Quarterly Journal of Economics 113, 531-552.

Stein, J., 1997, Internal capital markets and the competition for corporate resources, Journal of Finance 52, 111-133.

Villalonga, B., 2004a, Diversification discount or premium? New evidence from the business information tracking series, Journal of Finance 59, 479-506.

Villalonga, B., 2004b, Does diversification cause the 'diversification discount'? Financial Management 33, 5-27.

Whited, T., 2001, Is it inefficient investment that causes the diversification discount? Journal of Finance 56, 1667-1691. 


\section{Table 1: Summary Statistics}

This table provides summary statistics for the data in our sample over the period 1998-2005. $R_{i, t}$ is stock return over fiscal year t-1 to t. Excess Return is defined as $\mathrm{R}_{\mathrm{i}, \mathrm{t}}-\mathrm{RB}_{\mathrm{i}, \mathrm{t}}$, where $\mathrm{RB}_{\mathrm{i}, \mathrm{t}}$ is stock i's benchmark return over fiscal year t- 1 to t. All variables except $R_{i, t}$, Excess Return and Leverage are standardized by the lagged market value of equity. Cash Holdings is cash plus marketable securities. $\Delta$ Cash Holdings is the one-year change of cash holdings (Cash Holdings $s_{t}$ - Cash Holdings $s_{t-1}$ ). $\Delta$ Earnings is the one-year change of earnings before extraordinary items. $\Delta$ Net Assets is the one-year change of total assets minus cash holdings. $\triangle R \& D$ is the one-year change of research and development expenses. $\Delta$ Interest Expense is the one-year change of interest expenses. $\Delta$ Dividends is the one-year change of common dividends. Leverage is the ratio of debt to total assets. New Financing is net new equity issues (equity issued minus repurchases) plus net new debt issues (debt issued minus debt retired). More details on the definition of the variables are provided in Appendix.

\begin{tabular}{lccccc}
\hline & Mean & Median & 25th Percentile & 75th Percentile & Std. Dev. \\
\hline $\mathrm{R}_{\mathrm{i}, \mathrm{t}}$ & 0.1773 & 0.1271 & -0.2245 & 0.4962 & 0.7799 \\
Excess Return & 0.0321 & 0.0094 & -0.3226 & 0.3624 & 0.5459 \\
$\Delta$ Cash Holdings & 0.0140 & 0.0007 & -0.0354 & 0.0398 & 0.1368 \\
Cash Holdings $\mathrm{t}_{-1}$ & 0.1656 & 0.0938 & 0.0312 & 0.2311 & 0.1829 \\
$\Delta$ Earnings & 0.0139 & 0.0063 & -0.0365 & 0.0475 & 0.1448 \\
$\Delta$ Net Assets & 0.0456 & 0.0268 & -0.0450 & 0.1350 & 0.2947 \\
$\Delta$ R\&D & -0.0010 & 0.0000 & 0.0000 & 0.0021 & 0.0276 \\
$\Delta$ Interest Expenses & 0.0012 & 0.0000 & -0.0016 & 0.0030 & 0.0294 \\
$\Delta$ Dividends & -0.0001 & 0.0000 & 0.0000 & 0.0000 & 0.0070 \\
Leverage & 0.2014 & 0.1549 & 0.0079 & 0.3360 & 0.2015 \\
New Financing & 0.0391 & 0.0027 & -0.0258 & 0.0664 & 0.1584 \\
\hline
\end{tabular}




\section{Table 2: The Value of Cash Holdings}

This table reports the value of cash holdings. The dependent variable is Excess Return defined as $\mathrm{R}_{\mathrm{i}, \mathrm{t}}-$ $\mathrm{RB}_{\mathrm{i}, \mathrm{t}}$. All variables except Excess Return, Firm Diversification, and Leverage are standardized by the lagged market value of equity. Cash Holdings is cash plus marketable securities. $\Delta$ Cash Holdings is the

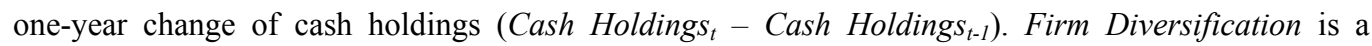
dummy variable that equals 1 for diversified firms and 0 for single-segment firms. $\Delta$ Earnings is the one-year change of earnings before extraordinary items. $\Delta$ Net Assets is the one-year change of total assets minus cash holdings. $\triangle R \& D$ is the one-year change of research and development expenses. $\Delta$ Interest Expense is the one-year change of interest expenses. $\Delta$ Dividends is the one-year change of common dividends. Leverage is the ratio of debt to total assets. New Financing is net new equity issues plus net new debt issues.

\begin{tabular}{|c|c|c|c|c|}
\hline & coef. & p-value & coef. & p-value \\
\hline Intercept & 0.003 & 0.60 & 0.003 & 0.63 \\
\hline$\Delta$ Cash Holdings & 1.245 & 0.01 & 1.295 & 0.01 \\
\hline Firm Diversification $* \Delta$ Cash Holdings & & & -0.160 & 0.01 \\
\hline Firm Diversification & & & 0.001 & 0.98 \\
\hline$\Delta$ Earnings & 0.649 & 0.01 & 0.648 & 0.01 \\
\hline$\Delta$ Net Assets & 0.284 & 0.01 & 0.284 & 0.01 \\
\hline$\Delta \mathrm{R} \& \mathrm{D}$ & 0.742 & 0.01 & 0.744 & 0.01 \\
\hline$\Delta$ Interest Expenses & -1.305 & 0.01 & -1.309 & 0.01 \\
\hline$\Delta$ Dividends & 2.814 & 0.01 & 2.821 & 0.01 \\
\hline Cash Holdings $_{\mathrm{t}-1}$ & 0.194 & 0.01 & 0.195 & 0.01 \\
\hline Leverage & -0.224 & 0.01 & -0.223 & 0.01 \\
\hline Cash Holdings $_{\mathrm{t}-1} * \Delta$ Cash Holdings & -0.726 & 0.01 & -0.741 & 0.01 \\
\hline Leverage $* \Delta$ Cash Holdings & -0.509 & 0.01 & -0.478 & 0.01 \\
\hline New Financing & 0.011 & 0.65 & 0.007 & 0.75 \\
\hline Observations & \multicolumn{2}{|c|}{28563} & \multicolumn{2}{|c|}{28563} \\
\hline Adjusted $\mathrm{R}^{2}$ & \multicolumn{2}{|c|}{0.13} & \multicolumn{2}{|c|}{0.14} \\
\hline
\end{tabular}

\begin{tabular}{ll|ll}
\hline \multicolumn{4}{c}{ The marginal value of \$1 } \\
\hline \multirow{2}{*}{ Whole sample } & $\$ 1.02$ & $\begin{array}{l}\text { Single-segment firms } \\
\text { Diversified firms }\end{array}$ & $\$ 1.08$ \\
& & $\$ 0.92$ \\
\hline
\end{tabular}


Table 3: Regressions for Financially Unconstrained and Constrained Firms

This table reports the results using financial constraints criteria. The regression results are presented across groups of financially unconstrained and constrained firms (see text for definitions). Financial constraints criteria are: size (Panel A), size and payout (Panel B), and size and rating (Panel C). The dependent variable is Excess Return defined as $\mathrm{R}_{\mathrm{i}, \mathrm{t}}-\mathrm{RB}_{\mathrm{i}, \mathrm{t}}$. All variables except Excess Return, Firm Diversification, and Leverage are standardized by the lagged market value of equity. Cash Holdings is cash plus marketable securities. $\Delta$ Cash Holdings is the one-year change of cash holdings (Cash Holdings $_{t}$ - Cash Holdings $s_{t-1}$ ). Firm Diversification is a dummy variable that equals 1 for diversified firms and 0 for single-segment firms. $\triangle$ Earnings is the one-year change of earnings before extraordinary items. $\Delta$ Net Assets is the one-year change of total assets minus cash holdings. $\Delta R \& D$ is the one-year change of research and development expenses. $\Delta$ Interest Expense is the one-year change of interest expenses. $\Delta$ Dividends is the one-year change of common dividends. Leverage is the ratio of debt to total assets. New Financing is net new equity issues plus net new debt issues.

Panel A. Financial constraints criteria: Size

\begin{tabular}{|c|c|c|c|c|}
\hline & \multicolumn{2}{|c|}{ Unconstrained } & \multicolumn{2}{|c|}{ Constrained } \\
\hline & coef. & p-value & coef. & $\mathrm{p}$-value \\
\hline Intercept & 0.022 & 0.01 & -0.054 & 0.01 \\
\hline$\Delta$ Cash Holdings & 1.165 & 0.01 & 1.368 & 0.01 \\
\hline Firm Diversification $* \Delta$ Cash Holdings & -0.145 & 0.05 & -0.161 & 0.02 \\
\hline Firm Diversification & -0.029 & 0.01 & 0.015 & 0.13 \\
\hline$\Delta$ Earnings & 0.747 & 0.01 & 0.626 & 0.01 \\
\hline$\Delta$ Net Assets & 0.264 & 0.01 & 0.335 & 0.01 \\
\hline$\Delta \mathrm{R} \& \mathrm{D}$ & 0.297 & 0.25 & 0.810 & 0.01 \\
\hline$\Delta$ Interest Expenses & -1.585 & 0.01 & -1.676 & 0.01 \\
\hline$\Delta$ Dividends & 2.079 & 0.01 & 4.858 & 0.01 \\
\hline Cash Holdings $_{\mathrm{t}-1}$ & 0.143 & 0.01 & 0.308 & 0.01 \\
\hline Leverage & -0.155 & 0.01 & -0.144 & 0.01 \\
\hline Cash Holdings $_{\mathrm{t}-1} * \Delta$ Cash Holdings & -0.763 & 0.01 & -0.835 & 0.01 \\
\hline Leverage $* \Delta$ Cash Holdings & -0.180 & 0.26 & -0.861 & 0.01 \\
\hline New Financing & -0.190 & 0.01 & 0.165 & 0.01 \\
\hline Observations & \multicolumn{2}{|c|}{13441} & \multicolumn{2}{|c|}{15122} \\
\hline Adjusted $\mathrm{R}^{2}$ & \multicolumn{2}{|c|}{0.12} & \multicolumn{2}{|c|}{0.14} \\
\hline
\end{tabular}

\section{The marginal value of $\$ 1$}

\begin{tabular}{lcc} 
& Unconstrained & Constrained \\
\hline Single-segment firms & $\$ 1.03$ & $\$ 1.12$ \\
Diversified firms & $\$ 0.88$ & $\$ 0.96$ \\
\hline
\end{tabular}


Panel B. Financial constraints criteria: Size and payout

\begin{tabular}{|c|c|c|c|c|}
\hline & \multicolumn{2}{|c|}{ Unconstrained } & \multicolumn{2}{|c|}{ Constrained } \\
\hline & coef. & $\mathrm{p}$-value & coef. & $\mathrm{p}$-value \\
\hline Intercept & 0.017 & 0.14 & -0.055 & 0.01 \\
\hline$\Delta$ Cash Holdings & 1.339 & 0.01 & 1.366 & 0.01 \\
\hline Firm Diversification $* \Delta$ Cash Holdings & -0.199 & 0.09 & -0.168 & 0.02 \\
\hline Firm Diversification & -0.017 & 0.12 & 0.023 & 0.05 \\
\hline$\Delta$ Earnings & 0.890 & 0.01 & 0.598 & 0.01 \\
\hline$\Delta$ Net Assets & 0.243 & 0.01 & 0.336 & 0.01 \\
\hline$\Delta \mathrm{R} \& \mathrm{D}$ & 0.317 & 0.52 & 0.726 & 0.01 \\
\hline$\Delta$ Interest Expenses & -3.100 & 0.01 & -1.585 & 0.01 \\
\hline$\Delta$ Dividends & 2.958 & 0.01 & 6.304 & 0.01 \\
\hline Cash Holdings $_{\mathrm{t}-1}$ & 0.119 & 0.01 & 0.307 & 0.01 \\
\hline Leverage & -0.116 & 0.01 & -0.143 & 0.01 \\
\hline Cash Holdings $_{\mathrm{t}-1} * \Delta$ Cash Holdings & -1.554 & 0.01 & -0.811 & 0.01 \\
\hline Leverage $* \Delta$ Cash Holdings & -0.450 & 0.31 & -0.904 & 0.01 \\
\hline New Financing & -0.186 & 0.01 & 0.177 & 0.01 \\
\hline Observations & \multicolumn{2}{|c|}{4539} & \multicolumn{2}{|c|}{12650} \\
\hline Adjusted $\mathrm{R}^{2}$ & \multicolumn{2}{|c|}{0.11} & \multicolumn{2}{|c|}{0.15} \\
\hline
\end{tabular}

The marginal value of $\$ 1$

\begin{tabular}{lcc} 
& Unconstrained & Constrained \\
\hline Single-segment firms & $\$ 1.10$ & $\$ 1.12$ \\
Diversified firms & $\$ 0.90$ & $\$ 0.95$ \\
\hline
\end{tabular}

Panel C. Financial constraints criteria: Size and rating

\begin{tabular}{|c|c|c|c|c|}
\hline & \multicolumn{2}{|c|}{ Unconstrained } & \multicolumn{2}{|c|}{ Constrained } \\
\hline & coef. & $\mathrm{p}$-value & coef. & $\mathrm{p}$-value \\
\hline Intercept & 0.023 & 0.14 & -0.064 & 0.01 \\
\hline$\Delta$ Cash Holdings & 1.127 & 0.01 & 1.467 & 0.01 \\
\hline Firm Diversification * $\Delta$ Cash Holdings & -0.231 & 0.05 & -0.097 & 0.09 \\
\hline Firm Diversification & -0.041 & 0.01 & 0.014 & 0.19 \\
\hline$\Delta$ Earnings & 0.900 & 0.01 & 0.654 & 0.01 \\
\hline$\Delta$ Net Assets & 0.215 & 0.01 & 0.326 & 0.01 \\
\hline$\Delta \mathrm{R} \& \mathrm{D}$ & -0.270 & 0.58 & 0.725 & 0.01 \\
\hline$\Delta$ Interest Expenses & -1.628 & 0.01 & -1.656 & 0.01 \\
\hline$\Delta$ Dividends & 4.300 & 0.01 & 4.827 & 0.01 \\
\hline Cash Holdings $_{\mathrm{t}-1}$ & 0.286 & 0.01 & 0.388 & 0.01 \\
\hline Leverage & -0.085 & 0.02 & -0.146 & 0.01 \\
\hline Cash Holdings $_{\mathrm{t}-1} * \Delta$ Cash Holdings & -0.553 & 0.02 & -1.665 & 0.01 \\
\hline Leverage $* \Delta$ Cash Holdings & -0.205 & 0.27 & -0.705 & 0.01 \\
\hline New Financing & -0.145 & 0.01 & 0.200 & 0.01 \\
\hline Observations & \multicolumn{2}{|c|}{5947} & \multicolumn{2}{|c|}{15017} \\
\hline Adjusted $\mathrm{R}^{2}$ & \multicolumn{2}{|c|}{0.13} & \multicolumn{2}{|c|}{0.14} \\
\hline
\end{tabular}

The marginal value of $\$ 1$

\begin{tabular}{lcc} 
& Unconstrained & Constrained \\
\hline Single-segment firms & $\$ 1.01$ & $\$ 1.07$ \\
Diversified firms & $\$ 0.77$ & $\$ 0.98$ \\
\hline
\end{tabular}


Table 4: The Impact of Corporate Governance

This table reports the impact of corporate governance. The dependent variable is Excess Return defined as $\mathrm{R}_{\mathrm{i}, \mathrm{t}}-\mathrm{RB}_{\mathrm{i}, \mathrm{t}}$. All variables except Excess Return, Firm Diversification, Poor Governance, and Leverage are standardized by the lagged market value of equity. Cash Holdings is cash plus marketable securities. $\triangle$ Cash Holdings is the one-year change of cash holdings (Cash Holdings $t_{t}$ - Cash Holdings $s_{t-1}$ ). Firm Diversification is a dummy variable that equals 1 for diversified firms and 0 for single-segment firms. Poor Governance is a dummy variable that equals 1 if the Gompers et al. index of a firm is within the top 90 percentile (or top 75 percentile as an alternative cutoff point) of the subsample. $\Delta$ Earnings is the one-year change of earnings before extraordinary items. $\Delta$ Net Assets is the one-year change of total assets minus cash holdings. $\triangle R \& D$ is the one-year change of research and development expenses. $\triangle$ Interest Expense is the one-year change of interest expenses. $\Delta$ Dividends is the one-year change of common dividends. Leverage is the ratio of debt to total assets. New Financing is net new equity issues plus net new debt issues.

\begin{tabular}{|c|c|c|c|c|}
\hline & \multicolumn{2}{|c|}{$\begin{array}{l}\text { Poor Governance Criteria } \\
\text { Gindex } \geq 12 \text { (Top } 90 \text { Pct) }\end{array}$} & \multicolumn{2}{|c|}{$\begin{array}{l}\text { Poor Governance Criteria } \\
\text { Gindex } \geq 11 \text { (Top } 75 \text { Pct) }\end{array}$} \\
\hline & coef. & p-value & coef. & p-value \\
\hline Intercept & 0.071 & 0.01 & 0.072 & 0.01 \\
\hline$\Delta$ Cash Holdings & 1.466 & 0.01 & 1.460 & 0.01 \\
\hline Firm Diversification $* \Delta$ Cash Holdings & -0.255 & 0.01 & -0.252 & 0.01 \\
\hline Firm Diversification $* \Delta$ Cash Holdings $*$ Poor Governance & -0.301 & 0.05 & -0.251 & 0.08 \\
\hline Firm Diversification & -0.026 & 0.01 & -0.027 & 0.01 \\
\hline Poor Governance & -0.023 & 0.04 & -0.014 & 0.13 \\
\hline$\Delta$ Earnings & 0.667 & 0.01 & 0.669 & 0.01 \\
\hline$\Delta$ Net Assets & 0.274 & 0.01 & 0.274 & 0.01 \\
\hline$\Delta \mathrm{R} \& \mathrm{D}$ & 0.589 & 0.02 & 0.591 & 0.02 \\
\hline$\Delta$ Interest Expenses & -2.331 & 0.01 & -2.336 & 0.01 \\
\hline$\Delta$ Dividends & 3.416 & 0.01 & 3.450 & 0.01 \\
\hline Cash Holdings $_{\mathrm{t}-1}$ & -0.051 & 0.11 & -0.052 & 0.11 \\
\hline Leverage & -0.093 & 0.01 & -0.094 & 0.01 \\
\hline Cash Holdings $_{\mathrm{t}-1} * \Delta$ Cash Holdings & -1.400 & 0.01 & -1.384 & 0.01 \\
\hline Leverage $* \Delta$ Cash Holdings & -1.151 & 0.01 & -1.143 & 0.01 \\
\hline New Financing & -0.238 & 0.01 & -0.236 & 0.01 \\
\hline Observations & \multicolumn{2}{|c|}{8242} & \multicolumn{2}{|c|}{8242} \\
\hline Adjusted $\mathrm{R}^{2}$ & \multicolumn{2}{|c|}{0.12} & \multicolumn{2}{|c|}{0.11} \\
\hline
\end{tabular}

\begin{tabular}{lcc}
\hline & \multicolumn{2}{c}{ The marginal value of $\$ \mathbf{1}$} \\
& Poor Governance Criteria & Poor Governance Criteria \\
& Gindex $\geq 12$ (Top 90 Pct) & Gindex $\geq 11$ (Top 75 Pct) \\
\hline Single-segment firms & $\$ 1.09$ & $\$ 1.08$ \\
Diversified firms & $\$ 0.83$ & $\$ 0.83$ \\
Diversified firms with poor governance & $\$ 0.53$ & $\$ 0.58$ \\
\hline
\end{tabular}


Table 5A: The Value of Cash Holdings

\section{— Alternative Measure of the Unexpected Change in Cash Holdings}

This table reports the value of cash holdings using an alternative measure of the unexpected change in cash holdings. Firm size is the criteria of financial constraints. The dependent variable is Excess Return defined as $\mathrm{R}_{\mathrm{i}, \mathrm{t}}-\mathrm{RB}_{\mathrm{i}, \mathrm{t}}$. All variables except Excess Return, Firm Diversification, and Leverage are standardized by the lagged market value of equity. Cash Holdings is cash plus marketable securities. $\Delta$ Net Cash Holdings is the realized change in cash holdings minus the average change in cash holdings in the corresponding benchmark portfolio over the same period (see text for more details). Firm Diversification is a dummy variable that equals 1 for diversified firms and 0 for single-segment firms. $\Delta$ Earnings is the one-year change of earnings before extraordinary items (Earnings $s_{t}-$ Earnings $\left._{t-1}\right)$. $\Delta N e t$ Assets is the one-year change of total assets minus cash holdings. $\Delta R \& D$ is the one-year change of research and development expenses. $\Delta$ Interest Expense is the one-year change of interest expenses. $\Delta$ Dividends is the one-year change of common dividends. Leverage is the ratio of debt to total assets. New Financing is net new equity issues plus net new debt issues.

\begin{tabular}{lcc|cccc}
\hline & \multicolumn{2}{c}{ Entire Sample } & \multicolumn{2}{c}{ Unconstrained } & \multicolumn{2}{c}{ Constrained } \\
\hline Intercept & coef. & p-value & coef. & p-value & coef. & p-value \\
$\Delta$ Net Cash Holdings & -0.016 & 0.01 & 0.037 & 0.01 & -0.054 & 0.01 \\
Firm Diversification * $\Delta$ Net Cash Holdings & 1.394 & 0.01 & 1.239 & 0.01 & 1.448 & 0.01 \\
Firm Diversification & -0.155 & 0.01 & -0.143 & 0.05 & -0.166 & 0.01 \\
$\Delta$ Earnings & 0.001 & 0.98 & -0.030 & 0.01 & 0.017 & 0.10 \\
$\Delta$ Net Assets & 0.652 & 0.01 & 0.750 & 0.01 & 0.631 & 0.01 \\
$\Delta$ R\&D & 0.291 & 0.01 & 0.264 & 0.01 & 0.316 & 0.01 \\
$\Delta$ Interest Expenses & 0.698 & 0.01 & 0.242 & 0.35 & 0.767 & 0.01 \\
$\Delta$ Dividends & -1.427 & 0.01 & -1.658 & 0.01 & -1.333 & 0.01 \\
Cash Holdingst & 2.926 & 0.01 & 2.041 & 0.01 & 4.067 & 0.01 \\
Leverage & 0.250 & 0.01 & 0.169 & 0.01 & 0.348 & 0.01 \\
Cash Holdings ${ }_{t-1}^{*} \Delta$ Net Cash Holdings & -0.147 & 0.01 & -0.151 & 0.01 & -0.172 & 0.01 \\
Leverage * $\Delta$ Net Cash Holdings $_{\text {New Financing }}^{-1.211}$ & -0.01 & -1.101 & 0.01 & -1.262 & 0.01 \\
\hline Observations & -0.706 & 0.01 & -0.219 & 0.17 & -0.932 & 0.01 \\
Adjusted ${ }^{2}$ & -0.025 & 0.28 & -0.190 & 0.01 & 0.148 & 0.01 \\
\hline
\end{tabular}

\begin{tabular}{lc|cc}
\hline \multicolumn{4}{c}{ The marginal value of \$1 } \\
\hline & Entire Sample & Unconstrained & Constrained \\
\hline Single-segment firms & $\$ 1.08$ & $\$ 1.05$ & $\$ 1.11$ \\
Diversified firms & $\$ 0.93$ & $\$ 0.91$ & $\$ 0.94$ \\
\hline
\end{tabular}




\section{Table 5B: The Value of Cash Holdings: The Impact of Corporate Governance - Alternative Measure of the Unexpected Change in Cash Holdings}

This table reports the impact of corporate governance with an alternative measure of the unexpected change in cash holdings. The dependent variable is Excess Return defined as $\mathrm{R}_{\mathrm{i}, \mathrm{t}}-\mathrm{RB}_{\mathrm{i}, \mathrm{t}}$. All variables except Excess Return, Firm Diversification, Poor Governance, and Leverage are standardized by the lagged market value of equity. Cash Holdings is cash plus marketable securities. $\Delta$ Net Cash Holdings is the realized change in cash holdings minus the average change in cash holdings in the corresponding benchmark portfolio over the same period (see text for more details). Firm Diversification is a dummy variable that equals 1 for diversified firms and 0 for single-segment firms. Poor Governance is a dummy variable that equals 1 if the Gompers et al. index of a firm is within the top 90 percentile (or top 75 percentile as an alternative cutoff point) of the subsample. $\Delta$ Earnings is the one-year change of earnings before extraordinary items $\left(\right.$ Earnings $_{t}-$ Earnings $\left._{t-1}\right)$. $\Delta$ Net Assets is the one-year change of total assets minus cash holdings. $\Delta R \& D$ is the one-year change of research and development expenses. $\Delta$ Interest Expense is the one-year change of interest expenses. $\Delta$ Dividends is the one-year change of common dividends. Leverage is the ratio of debt to total assets. New Financing is net new equity issues plus net new debt issues.

\begin{tabular}{|c|c|c|c|c|}
\hline & \multicolumn{2}{|c|}{$\begin{array}{l}\text { Poor Governance Criteria } \\
\text { Gindex } \geq 12 \text { (Top } 90 \text { Pct) }\end{array}$} & \multicolumn{2}{|c|}{$\begin{array}{l}\text { Poor Governance Criteria } \\
\text { Gindex } \geq 11 \text { (Top } 75 \text { Pct) }\end{array}$} \\
\hline & coef. & p-value & coef. & p-value \\
\hline Intercept & 0.075 & 0.01 & 0.082 & 0.01 \\
\hline$\Delta$ Net Cash Holdings & 1.486 & 0.01 & 1.468 & 0.01 \\
\hline Firm Diversification $* \Delta$ Net Cash Holdings & -0.225 & 0.09 & -0.245 & 0.05 \\
\hline Firm Diversification * $\Delta$ Net Cash Holdings $*$ Poor Governance & -0.343 & 0.07 & -0.288 & 0.08 \\
\hline Firm Diversification & -0.028 & 0.01 & -0.031 & 0.01 \\
\hline Poor Governance & -0.028 & 0.02 & -0.019 & 0.06 \\
\hline$\Delta$ Earnings & 1.235 & 0.01 & 1.189 & 0.01 \\
\hline$\Delta$ Net Assets & 0.307 & 0.01 & 0.286 & 0.01 \\
\hline$\Delta \mathrm{R} \& \mathrm{D}$ & 0.817 & 0.01 & 0.809 & 0.01 \\
\hline$\Delta$ Interest Expenses & -2.825 & 0.01 & -2.647 & 0.01 \\
\hline$\Delta$ Dividends & 3.865 & 0.01 & 3.633 & 0.01 \\
\hline Cash Holdings $_{\mathrm{t}-1}$ & -0.002 & 0.96 & -0.003 & 0.93 \\
\hline Leverage & -0.104 & 0.01 & -0.100 & 0.01 \\
\hline Cash Holdings $_{\mathrm{t}-1} * \Delta$ Net Cash Holdings & -0.922 & 0.01 & -0.919 & 0.01 \\
\hline Leverage $* \Delta$ Net Cash Holdings & -1.539 & 0.01 & -1.497 & 0.01 \\
\hline New Financing & -0.223 & 0.01 & -0.204 & 0.01 \\
\hline Observations & \multicolumn{2}{|c|}{8242} & \multicolumn{2}{|c|}{8242} \\
\hline Adjusted $\mathrm{R}^{2}$ & \multicolumn{2}{|c|}{0.12} & \multicolumn{2}{|c|}{0.12} \\
\hline
\end{tabular}

The marginal value of $\$ 1$

\begin{tabular}{lcc} 
& $\begin{array}{c}\text { Poor Governance Criteria } \\
\text { Gindex } \geq 12(\text { Top 90 Pct) }\end{array}$ & $\begin{array}{c}\text { Poor Governance Criteria } \\
\text { Gindex } \geq 11 \text { (Top 75 Pct) }\end{array}$ \\
\hline Single-segment firms & $\$ 1.08$ & $\$ 1.07$ \\
Diversified firms & $\$ 0.86$ & $\$ 0.83$ \\
Diversified firms with poor governance & $\$ 0.52$ & $\$ 0.54$ \\
\hline
\end{tabular}




\section{Table 6A: Probit Regression}

This table reports probit estimates. The dependent variable takes the value 1 for diversified firms and 0 for single-segment firms. Size is the logarithm of sales. EBIT is the ratio of earnings before interests and taxes to assets. Capital Expenditures is the ratio of capital expenditures to assets. $S \& P$ is a dummy that equals 1 when the firm is part of the S\&P index and 0 otherwise. Major Stock Exchange is a dummy that equals 1 if the firm is listed on Nasdaq, NYSE, or AMEX, and 0 otherwise. Fraction of Diversified Firms in the Industry is the fraction of all the firms in the industry that are diversified firms. Fraction of Industry Sales by Diversified Firms is the fraction of industry sales accounted for by diversified firms. GDP is Gross Domestic Product. GDP Growth is the growth rate of Gross Domestic Product.

\begin{tabular}{lcc}
\hline & coef. & p-value \\
\hline Intercept & -3.592 & 0.01 \\
Size & 0.071 & 0.01 \\
Size t-1 & -0.020 & 0.45 \\
Size t-2 & 0.085 & 0.01 \\
EBIT & 0.710 & 0.01 \\
EBIT t-1 & -0.711 & 0.01 \\
EBIT t-2 & 0.160 & 0.02 \\
Capital Expenditures & 0.562 & 0.01 \\
Capital Expenditures t-1 & 0.220 & 0.07 \\
Capital Expenditures t-2 & -0.017 & 0.87 \\
S\&P & 0.115 & 0.01 \\
Major Stock Exchange & 0.010 & 0.68 \\
Fraction of Diversified Firms in the Industry & -0.001 & 0.01 \\
Fraction of Industry Sales by Diversified Firms & 1.889 & 0.01 \\
GDP t-1 & 0.555 & 0.01 \\
GDP Growth & & 0.65 \\
\hline Observations & & \\
Pseudo R & & \\
\hline & & 0.14 \\
\hline
\end{tabular}




\section{Table 6B: Three Econometric Methods}

This table reports the results using three econometrics methods to control for the potential endogeneity problem (see text for more details). The dependent variable is Excess Return defined as $\mathrm{R}_{\mathrm{i}, \mathrm{t}}-\mathrm{RB}_{\mathrm{i}, \mathrm{t}}$. All variables except Excess Return, Firm Diversification, and Leverage are standardized by the lagged market value of equity. Cash Holdings is cash plus marketable securities. $\Delta$ Cash Holdings is the one-year change of cash holdings (Cash Holdings $s_{t}$ - Cash Holdings $s_{t-1}$ ). Firm Diversification is a dummy variable that equals 1 for diversified firms and 0 for single-segment firms. The fitted value is used in the instrumental variables estimation. $\Delta$ Earnings is the one-year change of earnings before extraordinary items. $\Delta$ Net Assets is the one-year change of total assets minus cash holdings. $\Delta R \& D$ is the one-year change of research and development expenses. $\Delta$ Interest Expense is the one-year change of interest expenses. $\Delta$ Dividends is the one-year change of common dividends. Leverage is the ratio of debt to total assets. New Financing is net new equity issues plus net new debt issues. Lambda is obtained from the probit estimates in Table 6A.

\begin{tabular}{|c|c|c|c|c|c|c|}
\hline & \multicolumn{2}{|c|}{$\begin{array}{c}\text { Heckman Two-Stage } \\
\text { Estimation: Second Stage }\end{array}$} & \multicolumn{2}{|c|}{$\begin{array}{c}\text { Instrumental Variables } \\
\text { Estimation: } \\
\text { Second Stage }\end{array}$} & \multicolumn{2}{|c|}{$\begin{array}{c}\text { Fixed Effect Estimation } \\
\text { (firm effects and year } \\
\text { effects not reported) }\end{array}$} \\
\hline & coef. & $p$-value & coef. & p-value & coef. & p-value \\
\hline Intercept & -0.012 & 0.17 & 0.052 & 0.01 & & \\
\hline$\Delta$ Cash Holdings & 1.316 & 0.01 & 1.435 & 0.01 & 1.278 & 0.01 \\
\hline Firm Diversification * $\Delta$ Cash Holdings & -0.145 & 0.01 & -0.334 & 0.01 & -0.118 & 0.02 \\
\hline Firm Diversification & -0.010 & 0.56 & -0.084 & 0.01 & -0.008 & 0.61 \\
\hline$\Delta$ Earnings & 0.672 & 0.01 & 0.640 & 0.01 & 0.566 & 0.01 \\
\hline$\Delta$ Net Assets & 0.293 & 0.01 & 0.234 & 0.01 & 0.210 & 0.01 \\
\hline$\Delta \mathrm{R} \& \mathrm{D}$ & 0.689 & 0.01 & 0.385 & 0.01 & 0.486 & 0.01 \\
\hline$\Delta$ Interest Expenses & -1.416 & 0.01 & -1.307 & 0.01 & -0.894 & 0.01 \\
\hline$\Delta$ Dividends & 3.008 & 0.01 & 2.545 & 0.01 & 2.069 & 0.01 \\
\hline Cash Holdings $_{\mathrm{t}-1}$ & 0.202 & 0.01 & 0.270 & 0.01 & 0.804 & 0.01 \\
\hline Leverage & -0.168 & 0.01 & -0.160 & 0.01 & -0.422 & 0.01 \\
\hline Cash Holdings $_{\mathrm{t}-1} * \Delta$ Cash Holdings & -0.797 & 0.01 & -1.545 & 0.01 & -0.842 & 0.01 \\
\hline Leverage $* \Delta$ Cash Holdings & -0.687 & 0.01 & -0.558 & 0.01 & -0.320 & 0.01 \\
\hline New Financing & -0.020 & 0.42 & 0.062 & 0.01 & 0.085 & 0.01 \\
\hline Lambda & 0.004 & 0.72 & & & & \\
\hline Observations & \multicolumn{2}{|c|}{27767} & \multicolumn{2}{|c|}{27767} & \multicolumn{2}{|c|}{27151} \\
\hline Adjusted $\mathrm{R}^{2}$ & \multicolumn{2}{|c|}{0.13} & \multicolumn{2}{|c|}{0.12} & \multicolumn{2}{|c|}{0.14} \\
\hline
\end{tabular}

\begin{tabular}{lccc}
\hline & \multicolumn{3}{c}{ The marginal value of \$1 } \\
\hline & $\begin{array}{c}\text { Heckman Two-Stage } \\
\text { Estimation }\end{array}$ & $\begin{array}{c}\text { Instrumental } \\
\text { Variables Estimation }\end{array}$ & $\begin{array}{c}\text { Fixed Effect } \\
\text { Estimation }\end{array}$ \\
\hline Single-segment firms & $\$ 1.08$ & $\$ 1.09$ & $\$ 1.07$ \\
Diversified firms & $\$ 0.93$ & $\$ 0.76$ & $\$ 0.95$ \\
\hline
\end{tabular}


Table 6C: Heckman Two-Stage Estimation

\section{- Financial Constraints and the Impact of Corporate Governance}

This table reports the second stage of the Heckman two-stage estimation. The dependent variable is Excess Return defined as $\mathrm{R}_{\mathrm{i}, \mathrm{t}}-\mathrm{RB}_{\mathrm{i}, \mathrm{t}}$. Columns 1-4 are presented across groups of financially unconstrained and constrained firms separated by size (see text for definitions). Columns 5 and 6 report the results with corporate governance variables. All variables except Excess Return, Firm Diversification, Poor Governance, and Leverage are standardized by the lagged market value of equity. Cash Holdings is cash plus marketable securities. $\triangle$ Cash Holdings is the one-year change of cash holdings. Firm Diversification is a dummy variable that equals 1 for diversified firms and 0 for single-segment firms. Poor Governance is a dummy variable that equals 1 if the Gompers et al. index of a firm is within the top 90 percentile of the subsample. $\Delta$ Earnings is the one-year change of earnings before extraordinary items. $\Delta N e t$ Assets is the one-year change of total assets minus cash holdings. $\Delta R \& D$ is the one-year change of research and development expenses. $\Delta$ Interest Expense is the one-year change of interest expenses. $\Delta$ Dividends is the one-year change of common dividends. Leverage is the ratio of debt to total assets. New Financing is net new equity issues plus net new debt issues. Lambda is obtained from the probit estimates in Table 6A.

\begin{tabular}{|c|c|c|c|c|c|c|}
\hline & \multicolumn{2}{|c|}{ Unconstrained } & \multicolumn{2}{|c|}{ Constrained } & \multicolumn{2}{|c|}{$\begin{array}{l}\text { Poor Governance Criteria } \\
\text { Gindex } \geq 12 \text { (Top } 90 \text { Pct) }\end{array}$} \\
\hline & coef. & p-value & coef. & p-value & coef. & p-value \\
\hline Intercept & 0.042 & 0.01 & -0.047 & 0.01 & 0.088 & 0.01 \\
\hline$\Delta$ Cash Holdings & 1.182 & 0.01 & 1.359 & 0.01 & 1.485 & 0.01 \\
\hline Firm Diversification $* \Delta$ Cash Holdings & -0.128 & 0.08 & -0.149 & 0.03 & -0.261 & 0.01 \\
\hline $\begin{array}{l}\text { Firm Diversification * } \Delta \text { Cash Holdings } \\
* \text { Poor Governance }\end{array}$ & & & & & -0.338 & 0.04 \\
\hline Firm Diversification & -0.067 & 0.01 & 0.005 & 0.88 & -0.089 & 0.01 \\
\hline Poor Governance & & & & & -0.017 & 0.17 \\
\hline$\Delta$ Earnings & 0.778 & 0.01 & 0.639 & 0.01 & 0.739 & 0.01 \\
\hline$\Delta$ Net Assets & 0.263 & 0.01 & 0.336 & 0.01 & 0.326 & 0.01 \\
\hline$\Delta \mathrm{R} \& \mathrm{D}$ & 0.373 & 0.16 & 0.774 & 0.01 & 0.597 & 0.03 \\
\hline$\Delta$ Interest Expenses & -1.877 & 0.01 & -1.687 & 0.01 & -2.719 & 0.01 \\
\hline$\Delta$ Dividends & 2.794 & 0.01 & 4.953 & 0.01 & 4.258 & 0.01 \\
\hline Cash Holdings $_{\mathrm{t}-1}$ & 0.160 & 0.01 & 0.297 & 0.01 & -0.065 & 0.06 \\
\hline Leverage & -0.140 & 0.01 & -0.145 & 0.01 & -0.099 & 0.01 \\
\hline Cash Holdings $\mathrm{t}_{\mathrm{t}-1} * \Delta$ Cash Holdings & -0.802 & 0.01 & -0.829 & 0.01 & -1.242 & 0.01 \\
\hline Leverage $* \Delta$ Cash Holdings & -0.138 & 0.39 & -0.883 & 0.01 & -1.268 & 0.01 \\
\hline New Financing & -0.175 & 0.01 & 0.158 & 0.01 & -0.278 & 0.01 \\
\hline Lambda & 0.026 & 0.09 & 0.005 & 0.83 & 0.047 & 0.01 \\
\hline Observations & \multicolumn{2}{|c|}{13223} & \multicolumn{2}{|c|}{14544} & \multicolumn{2}{|c|}{8242} \\
\hline Adjusted $\mathrm{R}^{2}$ & \multicolumn{2}{|c|}{0.11} & \multicolumn{2}{|c|}{0.15} & \multicolumn{2}{|c|}{0.12} \\
\hline
\end{tabular}

\begin{tabular}{lcc|c}
\hline & \multicolumn{2}{c}{ The marginal value of \$1 } \\
\hline & Unconstrained & Constrained & $\begin{array}{c}\text { Poor Governance Criteria } \\
\text { Gindex } \geq 12 \text { (Top 90 Pct) }\end{array}$ \\
\hline Single-segment firms & $\$ 1.05$ & $\$ 1.11$ & $\$ 1.10$ \\
Diversified firms & $\$ 0.92$ & $\$ 0.96$ & $\$ 0.84$ \\
Diversified firms with poor governance & & & $\$ 0.50$ \\
\hline
\end{tabular}

